Madrygal. Revista de Estudios Gallegos

ISSN: 1138-9664

\title{
Un achegamento ás relacións humanimais na literatura galega ${ }^{1}$
}

\author{
Ana Acuña Trabazo ${ }^{2}$
}

Recibido: 28 de febreiro de 2021 / Aceptado: 15 de xullo de 2021

Resumo. Este artigo pretende ser un achegamento á relación entre animais humanos e animais non humanos en diferentes autores e obras da literatura galega desde unha perspectiva ecocrítica. A través dos textos exemplifícase a separación entre animais humanos e non humanos en contextos marcados pola dominación, ilústrase a interconexión humanimal e, finalmente, móstrase a plurisensorialidade do animal non humano. Engádense, tamén, ensaios con testemuños orais reais que inciden na separación bíos zoe en situacións de violencia extrema.

Palabras chave: ecocrítica; estudos animais; literatura galega; zoopoética.

\section{[es] Una aproximación a las relaciones humanimales en la literatura gallega}

Resumen. Este artículo pretende ser una aproximación a la relación entre animales humanos y animales no humanos en diferentes autores y obras de la literatura gallega desde una perspectiva ecocrítica. A través de los textos se ejemplifica la separación entre animales humanos y no humanos en contextos marcados por la dominación y la violencia, se ilustra la interconexión humanimal y, finalmente, se muestra la plurisensorialidad del animal no humano. Se añaden, también, ensayos con testimonios orales reales que inciden en la separación bíos zoe en situaciones de violencia extrema.

Palabras clave: ecocrítica; estudios animales; literatura gallega; zoopoética.

\section{[en] An Approach to Human-Animal Relationships in Galician Literature}

\begin{abstract}
This article aims to be an approach to the relationship between human and non-human animals in different authors and works of Galician literature from an ecocritical pespective. Through the texts the separation between human and non-human animals is exemplified in contexts marked by domination, the human-animal interconnection is illustrated, and finally the plurisensory of the non-human animal is shown. Essays with real oral testimonies are also added that focus on zoe bio separation in situations of extreme violence.
\end{abstract}

Keywords: Ecocriticism; Animal Studies; Galician Literature; zoopoetics.

Sumario. 1. Introdución. 2. Separación entre bíos e zoe: dominación, marxinación e desigualdade na relación entre humanos e animais. 2.1. Animais e humanos en condicións bélicas. 2.2. Animais e humanos nos campos de concentración e na tortura. 2.3. Os animais humanos e non humanos no laboratorio e na granxa. 3. Continuidade entre bíos e zoe: identificación na relación humanimal. 3.1. Hibridación mariña. 3.2. Hibridación interespecie. 3.3. Hibridación mítica no mar e na terra. 3.4. Totemismo ou de cando os animais falaban. 3.5. Serás de morto se non fuches de vivo. 3.6. Humanimais da casa, fóra a alma. 4. Unicamente zoe: a plurisensorialidade animal. 5. Consideracións finais. 6. Referencias bibliográficas.

Como citar: Acuña Trabazo, A. (2021): "Un achegamento ás relacións humanimais na literatura galega", en Madrygal. Revista de Estudios Gallegos 24, pp. 15-32, DOI: http://dx.doi.org/10.5209/madr.80231.

\footnotetext{
A elaboración deste artigo forma parte do proxecto de investigación “The Animal Trope” (PGC2018-093545-B-100 MCIU/AEI/FEDER, UE).

2 Universidade de Vigo, Departamento de Filoloxía Galega e Latina.

Correo-e: ganime@uvigo.es; ORCID: https://orcid.org/0000-0002-9441-7450.
} 


\section{Introdución}

No presente ensaio imos seguir o fío dun elemento que permite distinguir a presenza dos animais nos textos literarios en lingua galega. Ese elemento é a relación entre bíos e zoe, é dicir, a relación entre a vida política, exclusivamente humana, e a vida dos animais como múltiple enerxía (Braidotti 2016, Baceiredo 2019). As seguintes palabras de Rosi Braidotti (2016: 147-148) afondan na distinción:

Esta visión vitalista da materia vivente despraza a fronteira entre a parte da vida (...) que sempre se lle reservara ao ántropos, isto é, o bíos, e o campo máis amplo da vida animal e non humana, tamén chamada zoe. A estrutura dinámica e autoorganizada da vida en canto zoe (...) é sinónimo de vitalidade xeradora. É a forza transversal que atravesa e reconecta especies, categorías e áreas antes segregadas. O igualitarismo zoecentrado é, para min, a clave do xiro postantropocéntrico: unha resposta materialista, laica, ben sentada e exenta de sentimentalismos fronte á oportunista mercantilización transespecífica da vida que constitúe a lóxica do capitalismo avanzado.

En primeiro lugar, deterémonos nalgunhas propostas literarias centradas nos efectos da violencia (en condicións bélicas, de tortura, de experimentación...) e que translocen a separación entre bíos e zoe. A continuación, afondaremos noutras propostas que mostran a continuidade entre bíos e zoe manifestada a través das relacións humanimais nas que o animal non humano pode converterse no meu outro significativo. Por último, abordaremos algúns textos - poucos- que proporcionan a plurisensorialidade do animal non humano. Con todo, debemos advertir que, en ocasións, as fronteiras dentro desta tripla distinción non son nítidas e pode haber zonas -léase obrasde intersección.

Para enmarcar o noso artigo, debemos indicar que partimos do marco teórico do ecofeminismo, ecocrítica, humanidades ambientais, literatura comparada para chegar á ética animal (Braidotti; Horta; Puleo; Tafalla; Velasco; Flys Junquera, Marrero e Barella; Parreño e Marrero; Escartín; Palacios...) e dun corpus variado de escritores ${ }^{3}$ que, sen pretensión de exhaustividade, proceden de diferentes épocas da historia da literatura galega (dende Vicente Risco, Ánxel Fole, Luís Pimentel, Manuel Lueiro Rey, Xosé Neira Vilas, Xosé Luís Franco Grande, pasando por Xosé Luís Méndez Ferrín, Lois Diéguez, Paco Martín, Miguel Anxo Murado, Xavier Queipo, Afonso Eiré, Adolfo Caamaño, Manuel Rivas, Francisco Castro, Xurxo Sierra Veloso, Héitor Picallo, Isaac Xubín... ata o colectivo In Nave Civitas) e xéneros (poesía, narrativa curta e longa, ensaio...). Sen afán de destacar, deterémonos máis naquelas propostas recentes por, talvez, menos coñecidas para o lector ou lectora.

\section{Separación entre bíos e zoe: dominación, marxinación e desigualdade na relación en- tre humanos e animais}

En canto á separación entre bíos e zoe, esta maniféstase claramente na violencia exercida sobre os animais no contexto da guerra, da experimentación e da explotación. Na nosa análise de textos de literatura galega e mais de testemuños orais non ficticios, comprobamos a instrumentalización ${ }^{4}$ de que son obxecto os animais non humanos nun corpus formado por distintos xéneros e localizado temporalmente en diferentes guerras (I e II Guerra Mundial, Guerra Civil, guerra da ex Iugoslavia...) e espazos (laboratorio, granxa...). En paralelo á vida real, os animais non humanos aparecen neses textos como servizo (cargadores, mensaxeiros, gardiáns, detectores ou mascotas) e como arma (de vinganza ou representación do asasinato dos humanos).

O uso dos animais non humanos como servizo e como arma baséase na idea de que os outros seres non humanos non son da mesma especie ca nós (especifismo) e, polo tanto, son dun tipo inferior que está ao noso dispor. Ese especifismo ten o adxectivo de antropocéntrico (Horta 2009 apud Velasco 2018: 49) por canto discrimina todos aqueles individuos que non pertencen á especie humana.

Óscar Horta (2018) desenvolveu amplamente os supostos falsos sobre as diferenzas entre humanos/as e outros animais e os prexuízos ou discriminacións que subxacen na consideración de que os animais non humanos

3 A presenza maioritaria de creadores, en masculino, neste artigo debeuse á necesidade de delimitación do corpus e a unha posible segunda parte centrada na análise de propostas literarias de muller.

4 Hannah Arendt (2006) insistiu en que a violencia sempre necesita ferramentas. 
están ao noso servizo. Trátase da ideoloxía da subordinación-dominación-explotación dos animais definida por A. Velasco (2018: 15) como "conxunto de crenzas que establece que os seres humanos teñen dereito a satisfacer todas as súas necesidades, sexan vitais ou superfluas, a custa da explotación dos animais". Este ser para outro dos animais non humanos lembra o paralelismo entre a explotación dos animais e a das mulleres, en concreto as características que a sociedade patriarcal esixe á muller (Velasco 2018: 269).

\subsection{Animais e humanos en condicións béli- cas}

No eido literario lonxe das nosas fronteiras, na novela de Michael Morpurgo Caballo de batalla (levada ao cine por Steven Spielberg) un narrador animal non humano, un cabalo, relata o uso que dos équidos fixo o exército británico e alemán durante a I Guerra Mundial. A través do cabalo Joey e de tantos outros presenciamos o seu carrexo de armas, o transporte de feridos e, a pesar de comportárense como heroes de guerra, a súa venda. Este trato desigual ocorre porque "As espécies subordinadas são empregues, logo, no seu valor simbólico ou no seu valor de uso, como material de trabalho, e descartadas quando já não servem como tal" (Baiceredo 2019: 19).

Durante a lectura da novela de Morpurgo, comprendemos o absurdo do conflito bélico e como, no medio da barbarie, os personaxes humanos encontran nos non humanos os seus mellores interlocutores, os seus amigos en calquera escalafón dos mandos (capitán ou soldado raso).

$\mathrm{Na}$ literatura galega non localizamos cabalos, senón un can que marcará a etapa do soldado Bonne Mort durante a I Guerra Mundial na ficción de Adolfo Caamaño Matar o heroe. Un can acompaña o protagonista na trincheira como moitos soldados adoitaban facer:

Quen non tiña can, coidaba gato, ou xílgaro cantor no medio da mortuoria melodía da guerra. Dalgún xeito había que aliviar a soidade e ausencia de caricias que se padecía na fronte, desa íntima calor proscrita entre a rudeza soldadesca. A miña dose de cariño nese inferno onde cadaquén se amarraba con unllas e dentes á supervivencia a min dábama esa mascotte un chihuahua ao que lle puxen Taxi. (Caamaño 2019: 212)

De ser unha simple mascota, un regalo ou un préstamo interesado dun tenente venezolano alistado na Lexión Estranxeira cuxa idea non fai feliz ao protagonista humano e á que non renuncia por non negarse "a unha petición dun mando" (Caamaño 2019: 220), o can Taxi transformarase nun soldado máis, "a viva imaxe da solidariedade (...) para un intre tan espiñento" (Ibid.: 220) como foi unha acción desesperada e heroica de Bonne Mort.

Ante as penalidades da trincheira, a irracionalidade da guerra e a soidade trala morte do único amigo non animal, o protagonista humano (Charles Bonne-Mort) decide embalsamar o can. A acción de embalsamar o animaliño non se trata dunha instrumentalización estética (Tafalla 2019) para a recreación, senón dunha maneira de manter vivo o animal como o protagonista quixera manter viva a nai tras asistir ao seu suicidio.

Dábame por pensar que os soldados eramos paxaros ao revés, aves subterráneas, desexosas de voar, pero prisioneiras na gaiola atrincheirada. (...)

Pero antes de que me dese por enterrarme así, no meu propio ser, tamén me dera por embalsamar. (...) Esa mesma noite da miña acción salvadora, co corpo inerme de Taxi ao meu lado, decidín salvar para sempre a súa efixie de can alegre e afouto. (...) Quería devolverlle a vida a todo o morto que amara e que perdera? Claro. E quen non querería cumprir desexo tan imposible? Pero, por irrealizable que semelle, contando como contaba coa miña pericia taxidérmica, tan sequera si podía conservarlles os corpos, non a alma, non a fala, non as caricias que me daban, as lambetadas de Taxi, os bicos e mecos de mamá. (Caamaño 2019: 226)

Con todo, can embalsamado e humano voarán de novo polos aires cando, nun bombardeo "rutineiro dos boches, un obús alcanzou a zona de trincheira" onde se refuxian. Como consecuencia, "O chihuahua quedou fulminado. Non se puido atopar nin un anaco da súa momia. E, malia quedar grave e definitivamente eivado, tamén esa vez" (Ibid.: 229) o protagonista humano esquiva a morte.

Ante o absurdo da loita, e a pesar de ser condecorado como heroe, o soldado Bonne Mort reclama un monumento para os non humanos, ademais de criticar o especifismo con argumentos de peso e de contrapoñer a humanidade do animal Taxi á bestialidade dos soldados na guerra:

Ás veces, amigo, dáme por pensar se non debería estar tamén nese templo do heroísmo galo, aínda que fose só un animal, aquel pequeno e 
afouto cadelo. Pero, tras ver morrer coma cans os pobres coloniais tonquineses e africanos na guerra, se os franceses aínda non descubrimos que as distintas cores da pel -e quizais, e por iso o digo, as diferenzas entre un can e un home, sendo moitas, no fondo non son tantas- non son óbice para abandonar un ser humano aos caprichos de escravistas e torturadores, quizais tampouco chegou o día de recoñecermos que o número de patas dun ser vivo, a linguaxe, ser máis ou menos peludo ou ter rabo ou non, non son razóns dabondo para abandonar un ser vivo a ese destino. Iso ensinoumo Taxi (...) Pois aprendino del, da admiración que o can tiña por min. Co engaiolado que quedaba coas miñas "conversas" con el, facíame sentir coma se eu fose un ser marabilloso, o sol incontestable que o alumeaba a el, o meu anano planeta canino. Eu sentía que Taxi -perdoa o que vou dicir, camarada, pero nunca vin un altruísmo máis puro- era o único ser do mundo que me quería máis a min do que podía quererse a si mesmo, e que poría a miña supervivencia por encima da súa sen dubidalo. De quen pode dicir un home iso? (...) Se errar é de humanos, perdoar, perdoar de verdade, é de animais. Así o creo tras convivir con el no horror da trincheira. Era tan intelixente o minúsculo animal, como enormemente bestas eramos alí os homes. E foi ese afecto del por min o que me fixo non dubidar en embalsamalo. (Ibid.: 340-341)

Descoñecemos se foi intencionada ou non esa referencia ao monumento por parte do autor, dado que foi real a negativa de París de alzar un monumento aos animais ${ }^{5}$. En todo caso, na novela de Adolfo Caamaño, Taxi e Bonne Mort, animal non humano e humano, sofren a mesma práctica violenta: os efectos dunha bomba, o non humano por segunda vez (a primeira morrera dun tiro de morteiro).

$\mathrm{O}$ animal non humano tamén pode aparecer como arma (de vinganza ou en representación do asasinato dos humanos) en textos de Miguel Anxo Murado, Xosé Manuel Sarille, Luís Pimentel ou testemuños orais recompilados, entre outros, por Aurora Marco e Llorenç Soler. Nuns e noutros, os animais non humanos foron violentados para aumentar o sufrimento dos seus donos no levantamento militar e na posterior ditadura.

En Polos fillos dos fillos (2004) de Xosé Manuel Sarille, tralo asasinato de familiares e veciños dun dos narradores protagonistas, tamén a este lle é arrebatada a infancia (con 14 anos) e ten trabucado o entendemento pola dor máis absoluta:

Os falanxistas mandárannos matar a Sil, o noso can que ladraba polas noites cando nos vixilaban desde a cortiña do Arboiro, por tras do muro. En menos de catro meses morreron dous dos meus amigos preferidos [can e cabalo]. Non me importou, os animais perderan todo o valor para min, tanto me daban. (Sarille 2004: 196)

$\mathrm{O}$ asasinato dos animais non humanos por seren estes seres sentientes e compañeiros dos humanos é usado na guerra como arma, como representación previa do asasinato dos donos. Pero non é a única razón, pois os estudos de Xosé Álvarez Castro (2013: 271) demostran que "O castigo económico non só cumpriu a función de represalia punitiva contra o inimigo, senón que tamén supuxo unha importante fonte de ingresos para a causa franquista".

Ademais da narrativa biográfica familiar de X. M. Sarille ${ }^{6}$, podemos engadir algúns exemplos procedentes da oralidade e recompilados nun ensaio por Aurora Marco. Neles, familiares de guerrilleiros e guerrilleiras relatan as requisas dos seus animais por parte dos golpistas $^{7}$ como castigo:

Os falanxistas e os enchufados eran os que roubaron e nos deixaron sen nada. Antes de ir para a prisión, xa nos desmantelaron a casa (...); levaron as vacas, tiñamos dúas parexas e terneiros para criar; levaron o gando miúdo, nove ou dez ducias entre cabras e ovellas. (...)

$\mathrm{O}$ matrimonio e os fillos foron postos en liberdade no mes de abril. Cando chegaron a Soulecín, a casa estaba baleira: alén de expoliaren todas as pertenzas, subhastaran o gando na praza de Viloira. Tiveron que comezar de novo: montar a casa e mercar animais (Marco 2011: 43 e 58$)$

5 A diferenza de Londres, Otawa e Bruxelas, París negouse a honrar os animais tal e como denuncia o seguinte titular de La Vanguardia 24/05/2018: "París se resiste a honrar a los animales de la gran Guerra".

Tamén na obra Seique de Susana Sánchez Arins.

Eduardo Pons Prades recolle testemuños orais de crianzas que explican o uso da morte do animal non humano como arma para amedrentalas. Velaquí un exemplo: "Me tuvieron con la soga al cuello cerca de ocho horas (...) Se sentaron cerca de mí para comer un bocado y uno de ellos apuntó a mi perra, Perla, que estaba sentada a mis pies, sin moverse, y la mató de un tiro. Y dijo que podía hacer otro tanto conmigo si no hablaba. Pero yo no solté prenda" (2004: 290). 
Sen chegar a ser asasinado, Turco, o can da familia De Dios Fernández que acompaña os guerrilleiros, pasa ao poder da Garda Civil tras un combate na Limia. O animal non humano foi utilizado para intentar "dar co grupo guerrilleiro. (...) Mais nunca o lograron" e acabou na comandancia de Ourense. Curiosamente, "cando Camilo de Dios saíu do cárcere, dez anos despois, foino ver mais o animal non o recoñeceu" (Ibid.: 399).

Peor é o padecemento dos paxaros ao servizo dun torturador poetizado por Luís Pimentel no poema titulado "Xogo ruín" (Sombra do aire na herba). A crueldade do "xogo" do neno sobre os paxaros trasládanos ao ensañamento sobre os indefensos ata o punto de ilusionalos coa liberdade antes de abatelos:

\author{
Aquil neno \\ pincháballe os ollos \\ ós paxaros; \\ e gustáballe ver saír \\ esa gotiña \\ de ar e de lus \\ ise rocío limpo \\ de mañanciñas frescas \\ Logo botábaos \\ a voar \\ e reíase de velos \\ toupar contra o valado \\ da súa casa, \\ con un ruído \\ moi triste
}

Creceu e foi de aqueles. (Pimentel 1983: 81)

A longa posguerra franquista tamén influíu na situación dos animais e da poboación por mor da repoboación do monte veciñal imposta polo réxime. Así se manifestaba unha das afectadas cuxas palabras recolle Ana Cabana ${ }^{8}$ (2019) e que foran gravadas por Llorenç Soler ( $O$ monte é noso, 1978):

E así quedamos sin agua, así quedamos sin monte e quedamos sin todo, e sin ovellas, que nós tiñamos un millagar delas e tivémolas que vender todas porque nolas fixeron vender porque non tiñamos onde as meter (...) despois tivémolas que vender todas, e logo, tiñamos máis de cincuenta ovellas, e coma nós todos.
Como arma e como vítimas aparecen os animais no durísimo relato de Miguel Anxo Murado "Zoolóxico" (Ruído. Relatos de guerra). O libro, como se indica ao seu inicio, "reflicte na súa maior parte o universo da guerra de Croacia do ano 1991, unha curta e brutal matanza" (Murado 2000: 9).

No conto, baixo o título dun lugar onde -en aparencia- se coidan os animais, agóchase realmente o seu asasinato provocado, unha matanza. Os personaxes humanos, maioritariamente soldados, son incapaces de percibir as calidades nin os dereitos dos non humanos. Nesta situación, cando non se aprecia a beleza nin dos animais nin da natureza, é máis doado que os acabemos destruíndo (Tafalla 2019). Como nos círculos do inferno dantesco, imos coñecendo o estado dos animais non humanos atrapados: as cebras morren abatidas, os pingüíns están danados polas armas, os chacais foron asasinados e colgados para que non comesen cadáveres humanos.

Todos os animais residentes son vítimas inocentes en zona de ninguén e ao servizo de quen a conquiste: "Os animais seguían alí mentres tanto. Á maioría non era posible trasladalos a outro lugar máis seguro. Tampouco había con que alimentalos. Agonizaban nas gaiolas, estarrecidos polo ruído" (Murado 2000: 68).

Mentres, algunhas das instalacións do zoolóxico, como a enfermería, son usadas para atender os humanos indiferentes ao sufrimento dos animais que os rodean:

Non todo o que contaba Hervé parecía proceder dunha mente racional nin pertencer á realidade, pero a medida que proseguiamos polo labirinto fétido de gaiolas abertas, e laios de bestas atrapadas, todo semellaba posible. Protexidos nos muros das gaiolas desfeitas, nas dependencias e nas oficinas, os milicianos facían o seu traballo, indiferentes ós estraños animais que, soltos e mortos de medo, vagaban por todas partes. (Ibid.: 69)

O zoolóxico é descrito polo narrador protagonista como unha arca de Noé que navega cara á destrución. O sufrimento máis intenso é o dun elefante ao que unha granada de morteiro lle estragou parte do ventre e ao que non lle é permitida a morte nin o sacrificio: non hai cal abonda que impida o cheiro e os militares non están dispostos a abandonar o zoolóxico.

\footnotetext{
8 Queremos deixar constancia do noso agradecemento a Ana Cabana polos seus comentarios e suxestións antes de ver a luz o seu estudo de 2019.
} 
"Houbo un tempo no que os elefantes eran armas de guerra. Os elefantes puideron ter conquerido Roma, o mundo enteiro" (Ibid.: 71). Estas son as palabras do comandante Hervé cuxa conduta se caracteriza polo dominio e a explotación fronte á conduta da médica voluntaria capaz de apreciar a beleza do elefante e sentir respecto e humildade, virtudes éticas fundamentais ante quen ten un sufrimento inmenso. Así se expresa a médica voluntaria: “... é a maior ferida que hai hoxe no mundo. (...) Ten case cen anos. (...) Naceu antes ca todos nós. (...) Pensaba tamén niso. En que o viu todo. Tardan en nacer e tardan en morrer" (Id.).

A dor deixa impasible ao comandante Hervé quen, a continuación e invadido polo odio, asasina un tigre de Bengala como instrumento de vinganza. Trátase dunha instrumentalización estética dos animais sinalada por Marta Tafalla (2019), é dicir, o seu uso como símbolo ou metáfora das ideas humanas do inimigo.

Para os chetniks é un símbolo. Eses que están aí fóra -dixo referíndose ós inimigos-. ¿Sabes o primeiro que fixo Arkan? Foi roubar un cachorro de tigre do zoo de Belgrado. Por iso se chaman a si mesmos "os tigres".

O animal revolveuse desesperado coa fame, triste e desnortado, absolutamente tolo.

Hervé engadiu, cun noxo visceral.

-Iso penso ás veces, que é o seu símbolo. E desde entón odio esta besta. ¿Sabes o que soño? Soño en que se isto dura abondo, o cachorro ha medrar e ha chegar o momento no que Arkan non terá con que alimentalo e o tigre o devorará a el.

Entón Hervé, inesperadamente, disparou sobre o animal coa súa pistola, e volveulle disparar unha e outra vez, fóra de si. Coma nun crime paixonal descargou a arma sobre o animal completamente, que quedou enrugado coma un trapo, contra un recanto.

Foi entón cando, durante uns instantes, parou o ruído naquela noite de pesadelo. (Murado 2000: 73)

Ata o final do relato o narrador protagonista non é consciente da dor dos animais aos que non lles está permitido nada no medio da crueldade humana:
Ó quedar en silencio, empezáronse a sentir, por primeira vez para min, os laios dos animais atrapados e desesperados de fame e o latexo ansioso e sonoro do enorme corazón do elefante, bombeando litros e litros de sangue, incapaz de morrer. (Ibid.: 74).

Escoitar o laio dos animais, sitúanos diante do ecocidio provocado polos humanos e, coma ao narrador protagonista, na Era da Soidade ${ }^{9}$. É o oído o que nos permite apreciar a natureza (Tafalla 2019: 177) e, neste caso, o narrador protagonista comeza a percibir os animais cando van desaparecer condenados á morte no medio da intensa contaminación acústica das bombas. Tal e como indica o título do libro de contos, estamos apagando as voces da natureza para substituílas por ruído.

Nos fragmentos transcritos, os animais non humanos existen para os animais humanos, para que nos sirvan, para convertelos en ferramentas e roubarlles a súa liberdade. A presenza humana só acarrea dor aos animais non humanos e estes tamén padecen os horrores da guerra. Aínda que algúns animais non humanos poidan ter relacións afectivas cos seus donos humanos nese espazo, a relación dos vencedores cos vencidos acabará provocando dor, cando non a morte, nos animais.

\subsection{Animais e humanos nos campos de con- centración e na tortura}

Tal e como formulou H. Arendt (2006: 85), é posible crear condicións baixo as cales os homes sexan deshumanizados, sen que isto signifique que se tornen animais. Trátase das condicións creadas nos campos de concentración $^{10}$, na tortura e na fame e nelas o máis claro signo de deshumanización é a ausencia de rabia e violencia. A literatura galega ofrécenos diferentes exemplos destas circunstancias extremas en relatos de Manuel Lueiro Rey, Xosé Luís Méndez Ferrín e Francisco Castro.

O conto de Lueiro Rey "Hundezelle" relata o resultado dunha experiencia límite vivida por Frank, xudeu alemán que, a petición da súa esposa Rafaela, imita o son dun can durante un concurso de voces animais na festa dunha aldea galega. $\mathrm{O}$ home, ata que sofre un ataque

9ermo preferido por algunhas persoas ao de antropoceno (Tafalla 2019: 149).

10 Afástase do propósito deste traballo profundar na violencia e nos campos de concentración onde se sitúa o "animal home fronte á loita pola vida", en palabras de Primo Levi (Levi 2015: 117). 
de tolemia, ladra "dunha maneira tan anguriada que os cans da aldea comezaron a ouvear enraibados, como se estivesen ollando cousas estrañas, como cando o medo lles mete o rabo entre as pernas e mexan por si" (Lueiro 2003: 226). A explicación desvélasenos despois de que Frank caia inconsciente:

Estivo dous anos no campo de concentración de Dachau. Os nazis, os mesmos que andaron por aquí, tivérono dous anos nunha cela de castigo onde só entraba un home, un home só e deitado, sempre do mesmo xeito, sen poder dar a volta. Chamábanlle "Hundezelle", que din que quere dicir o canil. E chamábanlle así porque o home que metían nesa cela tiña que pedir todo ladrando. Para facer as súas necesidades tiña que ladrar tres veces. Para comer dúas. Para pedir auga para beber catro veces. Ladrando coma un can. E Frank estivo nese canil dous anos. Ladrando, ladrando, día e noite, para mexar, para comer, para beber, para facer de corpo. ¡Dous anos! (Ibid.: 227)

En canto ao relato de Xosé Luís Méndez Ferrín, titulado significativamente "Animal" e pertencente a Cónica de nós, enmárcase na tortura padecida polo protagonista durante un secuestro. Tal e como se resolve o conto, o que o personaxe recoñece como o seu animal poida que non sexa máis ca o encontro consigo mesmo, coa súa propia condición non humana á que foi abocado tralas malleiras.

"A corda que aforca o mundo (Historia case real)", de Francisco Castro, relata o encontro do narrador protagonista adulto co cruel Xefe de Recursos Humanos d'A Empresa onde traballa e recoñece nel o asasino dos gatos da súa infancia para os que soñara un futuro. No presente descríbesenos o sufrimento humano e no pasado o padecemento animal baixo as poutas dun torturador porque todos "estamos gobernados por psicópatas. Ese dous por cento de aforcadores de gatos sen corazón" (Castro 2013: 22). O protagonista iguala o padecemento de todos os que están atrapados baixo o poder deste torturador de humanos e asasino de non humanos:

Este en concreto, había corenta anos usara unha corda real para enaquizar a vida, dun xeito cruel de cinco seres vivos, imaxino, só polo pracer de facer dano. Agora, facíao tamén coas persoas e, supoño, o seu deleite habería ser máis ou menos o mesmo.
Ou meirande, quizais. (Ibid.: 21)

\subsection{Os animais humanos e non humanos no laboratorio e na granxa}

A dor dos animais non humanos pode ter outro escenario diferente: a experimentación e a explotación. Tamén neste caso os animais non humanos sofren a instrumentalización, agora económica, nas mans de científicos con máis ou menos escrúpulos e incapaces de entender zoe. Neste novo espazo, seguindo a J. Berger (1980: 21) "los animales son siempre los observados" e "objetos de nuestra insaciable sed de conocimiento". Con todo, tal e como engade Berger, canto máis sabemos sobre eles, máis se afastan de nós. Este afastamento podemos comprobalo na narración longa Benvidos á cidade de Xurxo Sierra Veloso e en varios relatos de Xavier Queipo e de Xosé Luís Méndez Ferrín.

A novela Benvidos á cidade narra os experimentos de que son obxecto os animais (neste caso os visóns) por enriba de toda ética profesional tal e como un personaxe, caracterizado como experto universitario, lles explica ás autoridades:

Pensen que me están a falar de posibles experimentos ilegais, non sometidos a ningún tipo de control deontolóxico, sen compromiso ético nin obriga de comunicar os resultados á comunidade científica internacional. (...) Poderíalles falar dos catro veterinarios que morreron o ano pasado nunha granxa de Acerbaixán (...) Seica as ratas esas que se empregan habitualmente para probar as máquinas de afeitar- estaban algo famentas e saltaron sobre os veterinarios cunha violencia inesperada. E hai dous anos, no Canadá, unha manda de armiños provocou varias mortes entre os seus coidadores e en diversos animais da contorna. (...) Tolos e parvos hainos en todas as partes. Hóuboos tamén en Escocia, onde buscaron unha nova raza de gatos e acabaron criando tigres, e no Brasil, con aqueles abesouros que tan bos lle ían ser á conservación da flora do Amazonas. Por que non os había de haber aquí, entre nós, xogando coas probetas e aumentando as doses? (Sierra Veloso 2020: 82-83)

Durante a lectura da obra de Xurxo Sierra fáisenos presente o ensaio de Peter Singer, $\mathrm{Li}_{-}$ beración animal, así como as numerosas noticias reais ${ }^{11}$ sobre a solta de visóns por parte de grupos de liberación animal. Non obstante,

11 Recentemente, varios países decidiron sacrificar visóns e prohibir a súa cría por unha mutación do coronavirus. Como mostra, reproducimos varios titulares de La Vanguardia "Las terribles imágenes del sacrificio de 17 millones 
o relato sorprende pola caracterización dos humanos (persoas grises cun idealismo mal entendido) e pola ferocidade dos animais que sufriron modificacións xenéticas:

Había un proxecto secreto en Vis-El, unha cousa ilegal e perigosa. (...) O caso, señores, é que xa hai case dous anos que os visóns que nacen na nosa granxa son sometidos a experimentos científicos que non me atrevo a cualificar. Ao principio eran pequenas inxeccións dunha substancia chamada somatotropina (...) Os animais medraban e a pel brillaba dun xeito abraiante, con escintileos nunca vistos nesta clase de material. (...) $\mathrm{O}$ caso é que un día veu Costas, o fillo, e dixo que acababa de falar cuns veterinarios alemáns, que a somatotropina era cousa do pasado, que a investigación xenética melloraba día a día e que en poucos meses iamos estar en disposición de criar unha raza de visón verdadeiramente espectacular. (...) Eu sei que vostedes teñen a obriga de capturar os delincuentes que entraron na granxa e eu o deber de avisalos de que eses animais que arestora están soltos polos camiños son moi perigosos. Máis grandes e bonitos ca os visóns tradicionais, pero tamén máis intelixentes e agresivos. (Ibid.: 22-23)

O relato "Resistencia acuática" de Xavier Queipo non se refire a unha experimentación organizada, senón que nos presenta unha experimentación individual levada a cabo despois dunha xornada de traballo nunha casa do rural:

Eu xa experimentara en tempos coas formigas, mais nunca pensei que os escornabois -ditos tamén entre nós vacalouras ou cornanas- tivesen unha tal resistencia acuática. (...) Lembrando os experimentos que facía cando adolescente (...) collín un dos exemplares (...) e leveino ata o pío da auga que hai baixo o emparrado. (Queipo 2013: 90)

O narrador protagonista do conto de X. Queipo cualifica a súa acción de "maldade herdada dos meus tempos de investigación imberbe" (Ibid.: 91) e, despois de describir o comportamento do animal baixo o seu antollo de humano, recoñécese nel por un intre e isto provoca que se sinta "pequeno e ruín" (Id.).
"O castelo das poulas", un dos dez relatos que conforman Arraianos de Xosé Luís Méndez Ferrín, relata a experimentación sobre o comportamento "dunha manda de doce mastíns de Castro Laboreiro" (1999: 107) por parte dun coronel do exército. A visión do canil retratada polo autor desacouga:

Cans bourados, sometidos a bon trato, fartos, esfameados, a piques de morrer ou preparados para a procura, o ataque, a destrución, o esgazamento. Alí estaba a súa obra. O Coronel respirou a fondo o bafo dos doce animais, que adoptaron movemento de sumisión ao sentir que o amo estaba alí e falaba con eles. (Méndez Ferrín 1999: 109)

Por outra parte, no conto titulado "Mantis relixiosa", inserido en Percival e outras historias do mesmo Méndez Ferrín ${ }^{12}$, o vello e sabio D. Orl amósalle á súa sobriña o comportamento da mantis a partir da observación dos seus propios exemplares. A continuación o doutor relátalle o acontecido cunha muller, aparición inesperada e inexplicable, que actúa coma o insecto:

non era unha muller como as demais (...) Outa e delgadísima. Tiña uns ollos redondos e grandes..., a face triangular. Despois os brazos eran longos..., e as maos tan longas coma o antebrazo, cunhas unllas enormes; as maos viña a telas pregadas contra o antebrazo cando eu a vin, e daquela levaba unha túnica verde e estaba inmóbil, coma quen está en oración... (...) Ela miroume un intre, e despois fíxose atrás; ergueu a testa; ensinou os dentiños afiados; despregou os brazos esqueléticos, longos..., coaquilas maos longuísimas de unllas de ferro. Despois ergueuse vento, e a túnica verde alzóuselle por detrás e danzou de arredor do seu corpo. Ela tremou toda e púxose na punta dos pés, braceou no ar un xesto horríbel... Entramentres, veña fungar como unha cobra (...) Se un non se achegaba moito, ela estaba queda, coas enormes maos pregadas sóbor do antebrazo, en posición de quen reza ${ }^{13}$. Ao se alporizar, e abrir os brazos, e fungar (...) a muller aquela adoitaba as mesmas posturas, os mesmos hábitos e idéntico instinto que as barbantesas... (Méndez Ferrín 1994a: 89-90)

de visones" (10/11/2020) referido a Dinamarca ou "Ordenan sacrificar 1.000 visones en una granja de Ávila por covid" (27/01/2021) referido a Ávila.

12 É importante recordar o coñecemento teórico-práctico posuído por Méndez Ferrín do mundo animal dende pequeno cando cazaba "toda clase de insectos e mesmo os coleccionaba" (Salgado e Casado 1989: 38).

13 Esta postura que recorda a persoa que reza deulle diferentes nomes en Galicia tal e como demostramos nun estudo anterior (Acuña 1999). 
O fragmento ferriniano apunta a unha mestura de humanidade e animalidade ${ }^{14}$, propia do seguinte apartado deste artigo. O comportamento da muller barbantesa ${ }^{15}$, como a ollada do gato de Derrida fai "repensar o ser humano de acordo com esse contacto, essa zona de aceleramento que é a alteridade" (Brito 2021). O D. Orl procura unha explicación para este prodixio da muller barbantesa dende a evolución ou dende a doenza da entomomanía (pola que a muller insecto foi encerrada nun psiquiátrico). A hipótese pola que se inclina o doutor resulta máis inquietante posto que outorga ao insecto "vontade de superación" para acabar en humana:

Eu son evolucionista e sei que o home ascendeu á súa outa postura dende estados máis baixos aínda que o dos insectos... Imaxínate unha barbantesa de vontade de superación extraordinaria que se fixera muller..., que dun paso evolucionara a muller. (Méndez Ferrín 1994a: 90-91)

Nos seguintes apartados volveremos sobre a obra de Xosé Luís Méndez Ferrín pois nela é posible atopar tanto a relación humanimal como unicamente zoe, é dicir, a vida animal.

\section{Continuidade entre bíos e zoe: identifica- ción na relación humanimal}

Neste punto ilustraremos diferentes modos de hibridación humanimal (hibridación mariña, terrestre...) ou, incluso, hibridación interespecie en diferentes obras da historia da literatura galega.

$\mathrm{Na}$ máis recente literatura é posible encontrar a continuidade entre bíos e zoe como parte da proposta multidisciplicar (literaria, pictórica e musical) do colectivo lugrisián In Nave Civitas ${ }^{16}$ por canto contribúe a establecer vínculos afectivos coa natureza e os animais non humanos por medio da transxénese ou das ecomitoloxías.

Cómpre indicar que o colectivo se recoñece como lugrisián pola reapropiación dos motivos pictóricos e literarios do artista Urbano Lugrís. Esta reapropiación pode entenderse en clave ecolóxica, non só para manifestar a explotación e vulnerabilidade dos animais e a empatía con eles, senón tamén para expresar unha historia perdida ou, mellor, roubada para sempre polos problemas medioambientais actuais que son subproduto da cultura (Glotfelty 2010). As palabras da sabia do mar e habitante da Casa do Remo, protagonista de $O$ retorno dos homes mariños, son diáfanas sobre a perda do mar da Coruña:

A Coruña trocou a cultura da vida, do peixe, da fecundidade mariña, pola cultura da morte. $\mathrm{O}$ petróleo, os cadáveres de animais esmagados hai milleiros de anos (...). A cidade está furada, ten veas de ferro. Atravésana dende o porto ata Bens. Levan sangue negro, podrecido, cadáveres de animais que morreron no outro lado do tempo. (...) O cemento avanza, ditadura dos poderosos. Os grandes barcos, os iates dos ricos navegan na ría a canda os homes mariños. Pero nunca se han atopar, viven en mundos diferentes. (Souto 2021: 104)

A conciencia ambiental, entendida como preocupación polo mar e os seus habitantes non humanos, exprésase na literatura dalgúns membros do colectivo In Nave Civitas a través da identificación entre o corpo humano e o medio non humano ou mítico: peixe en Paco Souto; árbore, barco e paxaro en Xosé Iglesias; homes mariños e sereas en Xurxo Souto. Por estes tres autores imos comezar este apartado da relación humanimal.

\subsection{Hibridación mariña}

O poema "Metamorfose", pertencente ao poemario e Cain do desaparecido percebeiro Paco Souto, sitúa o país no ámbito mariñeiro e as persoas ${ }^{17}$ transformándose en peixes con escamas por pel, aletas por brazos e galadas para respirar:

vivo nun país de marea baixa

entre argazos e agullas de coral construímos a ilusión do solpor mentres o sol debuxa con quietude os seus pés na lagoa da tarde

Pénsese tamén na obra de F. Kafka (Gomes 2021).

15 Tal e como xa temos estudado, a barbantesa recibe o nome propio de Teresa nos textos de literatura de tradición oral.

16 Sobre este colectivo xa tivemos ocasión de pronunciarnos (Acuña e Rodríguez 2018).

17 Tal e como se visualiza a través dos debuxos dun home peixe creados por Viki Ribadulla. 
de enchernos a lúa

o noso país cativo

afogaría en sal océano

apenas é un baixo a romper

a pedra azul das augas

un salseiro de cobalto

sen terra para a labranza

sen augas de beber

sen respiro apenas

só nos queda arrincar a pel

e que veñan as escamas

empeñar brazos e pernas por aletas

e iluminar

coa tuberculose

as galadas que nos dean alento

maradentro (Souto 2016: 51)

\subsection{Hibridación interespecie}

O patrón e poeta Xosé Iglesias, no poema que dá título ao libro Transfusión oceánica, á parte de identificarse co océano, recoñece a mutación do seu corpo humano en árbore, barco e paxaro. Esta transxénese poética ${ }^{18}$ fainos pensar na interacción entre as distintas especies (humanas, animais e naturais) en termos de igualdade e no acceso ás perspectivas doutras subxectividades (árbore, barco, paxaro).

Eu creo que son humano reconvertido e sinto que nalgún momento sufrín transfusión oceánica porque este sangue do meu corpo non é sangue é auga salgada Sinto tamén que sufrín metamorfose non é nariz o meu senón proa non son brazos os meus senón amuras e as miñas costelas cadernas

Todo en min forma un esquelete naval Esta barriga que se afunde no mar é a estabilidade contra as ondas de costado Son home son barco son tantas cousas eu creo que son árbore porque sempre me chove sempre me venta sempre me da o sol Tamén creo que son paxaro porque os peixes venme voar entre as ondas e subo baixo fago siluetas acrobáticas ou simplemente voo raso Así me ven un paxaro voando no océano Miran cara arriba e alí estou coa proa as amuras a popa

Eu son mariñeiro e o mar móllame o alma salinízame e golpéame o corazón

e eu non podo facer máis nada senón ser árbore ser barco ser paxaro nada podo facer nada

porque mariñeiro son (Iglesias 2014: 75)

\subsection{Hibridación mítica no mar e na terra}

Se os poetas que acabamos de citar reflicten nos seus textos a transxénese humanimal, os libros de contos e as novelas de Xurxo Souto conteñen no seu interior moito de relatos míticos. Trátase de relatos ecolóxicos ou ecoloxistas nos que se solapa a metáfora, a norma, o mito e a vida, relatos moitos deles protagonizados por seres míticos cuxa razón de ser é a protección da natureza, de seres humanos aleccionados para respectala... Ecomitoloxías cun denominador común: a defensa do medio, dos recursos naturais e do aproveitamento sustentable da fauna, da flora, das riquezas minerais do contorno, como garantía de supervivencia (Pedrosa 2010: 316).

Unha mostra é o repetido, por esquecido, mito dos "homes mariños" 19 (vinculado cos mitos clásicos do Mediterráneo e coas tradicións populares do Atlántico Norte) cos que mantiñan trato os mariñeiros do Parrote (Coruña) e cuxa presenza era sinónimo de fartura na pesca. "Tan estreito era o trato que, ás veces, mesmo se permitían armar brincadeiras cos mareantes" (Souto 2007: 115). O sinal distintivo dos homes mariños coruñeses é que son "auténticos peixes que se relacionan cos humanos" (Ibid.: 117), aínda que, como se indica nos Contos da Coruña:

Dende hai tres séculos non sabemos na Coruña dos homes mariños. Símbolo do progresivo arredamento das cousas do mar. Oxalá que o seu reencontro signifique o reencontro coa esencia atlántica dos coruñeses, hoxe virados de costas á costa. A Coruña naceu do mar e no mar ten que ter o seu futuro. (Id.)

As sereas, tan próximas aos homes mariños, ocupan varias obras de Xurxo Souto ${ }^{20}$ : a modo

18 Ao labor poético, Xosé Iglesias engadiu recentemente o labor de artista plástico con creacións nas que ilustra a metamorfose interespecie (barcos en peixes, peixes en barcos...). Agradecemos ao autor que compartise connosco as súas creacións máis recentes.

19 Presente nos manifestos do colectivo In Nave Civitas e no final do poema de Xosé Iglesias "Man de Camelle" ( $A$ relixión do mar 2016: 139). Para saber máis pode lerse o capítulo de $\mathrm{M}^{\mathrm{a}}$ Alejandra Flores de la Flor de 2011.

20 E de escritores anteriores como Urbano Lugris, Álvaro Cunqueiro e Vicente Risco (Osorio 2021). 
de prefacio nos Contos do mar de Irlanda ou plenamente integradas na narración de $O \mathrm{re}$ torno dos homes mariños e $A$ gran travesía de Chiruca Macallás. Neste último libro, as baleas xunto co libro-peixe-sapo déixanse acompañar polos humanos e humanas nun tempo anterior á caza dos cetáceos. Ao carón das ecomitoloxías, a última novela citada denuncia as diversas formas de explotación do mar baixo o título "A esquilma, unha historia terrible".

No ámbito terrestre, outro caso de ecomitoloxía humanimal sería o do lobishome ou lobo da xente. Precisamente $O$ lobo da xente, subtitulado "lenda galega", é o relato de Vicente Risco que nos vai ocupar nas seguintes liñas. $\mathrm{O}$ experto etnógrafo e membro da xeración Nós relata o acontecido preto de Trives, segundo lle contaron, e reflexiona sobre o fascinio que exerce o lobo ${ }^{21}$ :

O certo é que o lobo é cousa de temer. Ningunha outra fera arrepía ós homes coma o lobo. El algo ten... O lobo ten ollar magnético; os seus ollos relocen coma brasas de noite (...) é un ollar que traspasa a un coma unha espada, e detén o sangue nas veas e deixa a un como a neve... Non cómpre tan sequera velo: abonda sentilo ouvear medoñento para que lle pase a un por todo o corpo o arreguizo astral, igual que se sente cando un atopa unha ánima en pena (...) Nin que o lobo fora cousa do outro mundo... E mais algo debe ter que ver con aquilo, e se cadra, os antigos algo souberon do seu misterio; imais agora os homes esqueceron tanta cousa! (Risco 1990: 29-30)

No relato de V. Risco o lobo é, en realidade, unha moza transformada en animal por unha mala fada materna que a obriga a "andar polo monte, con pel de lobo, namentres non pasen os anos que teñen que pasar, ou namentres non pérda-la pel de lobo" (Ibid.: 34). O home lobo ou lobo da xente sería "un ser híbrido que actúa coa intelixencia humana e coa furia desencadeada dunha besta salvaxe" (Garrosa 2005: 124). Por esta razón non é estraño que a muller loba do conto de Risco estale nun choro amargurado cando regresa dunha saída nocturna e se quenta ao lume nun sequeiro sen a súa pelica animal.

Os casos de licantropía son abondo coñecidos en moitas culturas (Docampo 2005) como "intensificación ao máximo" do temor ao
$1 \mathrm{obo}^{22}$, cuxa inquietante presenza está no imaxinario universal "como símbolo máis ou menos tanxíbel das forzas do mal e dos seus aliados", alén de "representación palpábel da forza do salvaxe" (Garrosa 2005: 113).

Un relato máis recente de licantropía na literatura galega foi escrito por Lois Diéguez e titulado "Como homes". Como en V. Risco, trala conversión do animal en humano, prodúcese o choro polo asasinato cometido:

Logo puxo ollos soñadores, o lobo. Ao pouco chegaron as convulsións. Sentia-se morrer. A verdade é que arremedar o ciclo da serpe inmortal nun animal tan grande e intelixente non debe ser precisamente voluntário. Durou-lle toda a noite, con vómito de carne non mastigada e desmaios, até que o corpo espido do home xurdiu, tan selvaxe, fermoso e vingativo como a própria criación. E na xanela, ao mirar para o parque anegado na luz grisalla do mencer, chorou. Chorou. (Diéguez 2013: 25)

\subsection{Totemismo ou de cando os animais fa- laban}

A cosmovisión da interdependencia e equilibrio entre os animais humanos e non humanos e a natureza, como elementos relacionados (non alleos nin estraños) nunha rede de parentesco, forma parte do pensamento de moitos pobos indíxenas tradicionais como o mesoamericano (González Torres 2018), shuar (Verdú e Shiki 2018), finoúrxicos antigos (Kailo 2015) etc.

Animais totémicos son os que reflicten a relación humanimal no poemario Estirpe e mais no relato Retorno a Tagen Ata de Xosé Luís Méndez Ferrín. Na sección "Estirpe", do libro homónimo, os poemas retrotráennos ao tempo das nosas orixes en que se escoitan as voces dos cabalos, das serpes e dos cervos. Tamén nese tempo eramos "portadores de escornabois na ollada" (Méndez Ferrín 1994b: 16), insecto que reaparece nun momento relevante da narración Retorno a Tagen Ata, pois con el a protagonista sente que "un anaco da fraga entrou, noitébrego, co grande insecto e meteu en min calquera cousa de enorme e antergo" (Méndez Ferrín 1987: 58).

Con estes animais da obra ferriniana parecen dialogar bastantes liñas escritas por Isaac

21 Como sucede cos visóns, o lobo está presente nas noticias da actualidade con titulares que separan bíos e zoe "La difícil convivencia con el lobo en Europa" (La Voz de Galicia do 14/02/2021).

22 A. Morgado García (2015) profunda neste aspecto. 
Xubín nas que un escornabois profetiza ao longo da novela Non hai outro camiño (Xubín 2016: 130 e 145) e mesmo unha barbantesa tatúa os brazos da Organización da narración Os largos e longos campos de liño azul (Xubín 2019: 110). O escornaboi profeta xa estaba presente na primeira obra publicada polo escritor e coa mesma función vaticinadora:

A profecía do vello Paddy

(O escornaboi que me falou en Zamáns cando [era estudante)

I

$\mathrm{Eu}$,

vello Paddy beyond the sea,

en Derry liberado e amarrado a este whiskey [que me inspira

dou fe de que ti, meu Danny Boy galego, empoleirado na pedra máis alta da Torre de [Breogán

como vello irlandés nos dondos montes de [Mourne e poñendo os [sentidos no levante,

escoitarás cabalos (...) (Xubín 2012: 47)

A obra poético-narrativa de Méndez Ferrín e a de Xubín que acabamos de citar son proba do totemismo, forma primitiva de relixión que coloca os animais no centro do universo como antepasados e parentes próximos, como creadores do mundo, como demiúrgos, como protectores do individuo e do clan, ou como dominadores dos elementos (Alinei 1983). Neste sentido, os estudos diacrónicos sobre o material semántico dos lingüistas e dialectólogos poden ser un complemento interesante para os estudos animais.

Aínda en relación cos nomes dos animais, en concreto dos insectos, debemos citar o conto "Forcadela" de Paco Martín. O relato, ademais da relación humanimal mantida entre $\mathrm{o}$ insecto e a protagonista feminina fronte ao protagonista masculino, explica as denominacións recibidas polo animal en función do seu comportamento. Como ocorre en moitos recitados infántís ${ }^{23}$, nunha situación de carencia (no relato, o remate dunha relación), o insecto convértese en coadxuvante e aliado da humana fronte a un antagonista e egoísta humano.

Buscou Rita entre os libros e soubo que Silvio tiña razón no que dixera pero que ó animal tamén se lle chamaba cadela de frade, forcadela, calabreta, cadela do abade... e máis nomes aínda. Gustoulle que fose así. Aquela enciclopedia falaba de distintas especies e aseguraba que era un animal inofensivo, polo menos para o home. O que non dicía o libro era algo que para a muller empezaba a resultar evidente: que o bicho medraba cos seus aloumiños. (Martín 2000: 109)

\subsection{Serás de morto se non fuches de vivo}

A especial relación humanimal á que nos referimos neste subapartado pode exemplificarse coa obra En salvaxe compaña de Manuel Rivas onde encontramos múltiples voces de animais non humanos: trescentos corvos, besta, ratos, gato, morcego, lagarto arnal, toupa, arañas, cascudas, sapos, formigas, pulgas, abellas, caracois, raposa, lesmas, avelaíñas... Con todo, as voces dos animais, almas transmigradas nunha metempsicose colectiva, seguen sendo humanas case na súa totalidade e nesta reencarnación os animais manteñen a súa memoria, o seu nome e oficio de cando foron persoas. Así, o lagarto arnal defínese como "home de pedras" (Rivas 2008: 107), o corvo Toimil devece por un tinto Amandi en ánfora de Buño (Ibid.: 24) e o morcego Gaspar non quere recordar:

Baixa de aí, Gaspar! Berrou agora imperativo Don Xil.

O morcego fixo unha chamativa elipse no ar e logo descendeu para pousarse sobre a billa dun dos bocois baleiros.

Mira, Gaspar. Este señor, explicou o músico Borborás sinalando o arnal, é unha acreditada autoridade no mundo dos sucesos e na arte do criminal entretemento. Aínda que con modestia; tivemos a oportunidade de que o noso lugar, polo teu caso, figurase en letras de molde na historia dos crimes pasionais. Cóntalle como foi.

Non me gusta recordar, dixo tristeiro o morcego.

Un esforzo, Gaspar, como se fose un conto. (Ibid.: 88)

A narración de Rivas mantense en dous planos (animais humanos vivos e non humanos vivos e mortos) que se mesturan e interactúan grazas ao personaxe do mudo Simón, un neno grande ao que, fronte a outros humanos, non lle roubaron a infancia.

Esta mesma idea da infancia como momento clave para a comunicación humanimal

23 Ocorre, por exemplo, nos recitados emitidos para a voaniña ou xoaniña (Acuña 1999). 
mantense no conto de Xosé Luís Franco Grande “O neno e o pónei” (2013):

E o rapaciño sabía, ou sospeitaba, ou intuía, que o Don Camilo rebulía de felicidade. Unha felicidade que el sentía que lla comunicaba a el mesmo, que se sentía envolto nunha nube de ledicia, como unha brétema, que lle chegaba dende os ollos, dende as patas, dende as orellas e dende todo o corpo vibrante e lixeiro do pónei. De todas cantas cousas vira ou atopara como novidade en todo val e arredores, ningunha lle daba tanta alegría como aquel pequeno animaliño (...) E o pónei de certo que enchía de alegría os prados onde pastaba (Ibid.: 36-37)

\subsection{Humanimais da casa, fóra a alma}

Á marxe das nosas orixes e máis próxima no tempo, podemos considerar continuidade entre bíos e zoe a mirada que tiña o campesiñado do século XX e que se pode ler en narracións de Xosé Neira Vilas e Afonso Eiré. Sobre esta circunstancia John Berger (1980: 29) postulou que trala marxinación dos animais vén a marxinación e eliminación da única clase que, ao longo da historia, permaneceu en contacto cos animais e perpetuou a sabedoría que acompaña ese contacto: o pequeno campesiñado.

O clásico de X. Neira Vilas Memorias dun neno labrego dedica un capítulo ao can "Pachín", un animal de compañía esencial para o campesiñado galego polas súas múltiples e ben feitas tarefas ${ }^{24}$. No capítulo citado e no titulado "Perdido", o entendemento entre o neno e o can parece total:

Nun tempo disque falaban os animales. (...) ¡Cántas cousas se cavilan! E todo dende que tiven a Pachín.

Porque Pachín si que falaba. Á súa maneira. Falaba cos ollos, co rabo, coas patas. Eu entendíao tan ben coma se pronunciase palabras. Non parecía un can. Tiña entendemento de persoa. (1979: 61-62)

O can, xunto coa vaca, protagonizan as creacións de Afonso Eiré. En efecto, dúas son as obras literarias de A. Eiré que nos serven de ponte entre este apartado e o seguinte por canto ilustran a relación humanimal e mais a plurisensorialidade animal nunha continuidade palpable para quen lea as dúas pezas narrativas. Desta maneira, tres contos do libro Eu tamén fun coas vacas ("A Cachorra" e "A vaca galega", por unha parte, e "O Sil e o Fermín, dous cans putañeiros", por outra), en boca dun narrador protagonista, dezaoito anos despois tomarán forma de novela en Memorias dunha vaca marela en boca dunha vaca rubia galega.

Nas seguintes citas, extraídas de cada un dos libros (contos de 2000 e novela 2018 respectivamente), alternan o narrador humano e a narradora non humana e pode apreciarse o cambio de perspectiva a partir dos mesmos feitos: presentación da vaca Cachorra, o seu enfrontamento coa outra vaca da casa, identificación da vaca galega coa casa e os seus habitantes humanos, diferenzas de comportamento coas pintas suízas e valoración negativa da transformación da explotación tradicional en granxa.

A Cachorra era a vaca mandamais da miña casa, pero non lle fora fácil coller o predominio. (2000: 15)

Eu son a Cachorra. Unha vaca. Pero non unha vaca calquera, son unha vaca marela. Unha rubia galega. Unha vaca de casa, agora enxermada e marota. (2018: 11)

Escornábanse cada vez que se botaban para fóra, sen chegar xa ao prado ou á chousa. (2000: 15)

Pero a Mora e mais eu comezamos a escornarnos xa antes de saír do curral, para tentar botar a primeira pola porta. Se queren que lles diga non sei por que. (2018: 13)

As vacas, constitución aparte e fóra a alma, son coma os humanos. Teñen cada unha as súas características e o seu xeito de comportarse. Pero iso eran as vacas de antes: as rubias, as galegas. Aquelas vacas posuían entendemento e nomes axeitados, adaptados ao seu físico e ao seu comportamento, que había que saber entender dende

24 Para coñecer máis sobre a predilección polo can nas diversas culturas, as características e a súa polisemia pode consultarse Orsanic (2018). Para o caso galego son ilustrativos moitos autores e xéneros. É o caso, por exemplo, de varios relatos do volume colectivo Pedigree (2013) e da narrativa de Ánxel Fole que nos desvela como no Caurel lles chaman aos cans "velliños, que é o xeito máis amantiño de chamar a alguén" (Fole 1981: 64). Incluso un destes animais, Pinto, sente saudades da terra onde naceu como lle pasa ao seu amo cando se traslada de Becerreá a Villacastín (Fole 1991). Por outra parte, un recente ensaio de Manuel Rivas aproxímanos aos segredos do can Toxo e, neste sentido, o autor confesa que nos debates sobre "se os animais teñen sentimentos, emocións e conciencia, eu adoito pensar en Toxo e evádome da conversa” (Rivas 2020: 63). 
cuxiñas. (...) Daquela, Cando as vacas eran vacas, tiñan entendemento. Unha familia de vacas duraba toda a vida dun home; unha vaca a dun mozote. (...) Despois viñeron as Pintas. As pintas de branco e negro. Chamábaselles Pinta, para que ela entendese, pero todo o mundo lle chamaba a Suíza (...) Ás suízas non lles interesa nada. Unicamente se teñen ou non teñen que comer. (...) Son todas iguais, uniformadas e uniformizadas, cos seus cornos cortados. E agora, coma os soldados, coma os presos, só son un número. (...) Agora xa non son vacas. Para que van ter nome se son unha copia de máquinas de facer leite, con data de caducidade temporal incorporada. (2000: 114-116)

Botáronme da miña corte, que volvera recuperar logo de tres anos, cando puxeron as pintas todas atadas no curral. Así cabían as que fixeran falta (...) As pintas eran as vacas leiteiras. Eu seguía a ser a vaca da casa. Pouco máis ca un nome, unha lembranza, unha testemuña de tempos pasados, do que fora a Casa do Cabanelas e xa non era. Antes era unha casa, agora unha explotación, a granxa. (2018: 169, 175)

Permítasenos un exemplo máis para abordar a relación co can en Eu tamén fun coas vacas e Memorias dunha vaca marela. No primeiro caso, no libro de contos, ao can dedícaselle un relato centrado nun costume comprendido polo narrador ("O Sil chegaba polo lameiro coma un baldreu borrachuzas. Arrastrábase e non se atrevía nin a levantar a cabeza, acochando na herba a súa pinta de putañeiro"; Eiré 2000: 75). No segundo caso, na novela memorialística da rubia galega, o can é observado pola vaca que certifica a comprensión do comportamento humano por parte do can ("Ollou de novo para o dono, como dicíndolle, "tranquilo, xa te entendo, seguro que é por esa becerra do diaño"; Eiré 2018: 32), pero, sobre todo, incide na forza da mirada ${ }^{25}$ entre os animais ("eu enxerguei nos seus ollos. El retratouse nos meus. Fixémonos amigos. Desde aquel día, pobre da persoa ou vaca que me tocara"; Ibid.: 35).

Como se pode apreciar, a novela Memorias dunha vaca marela de Afonso Eiré sería un exemplo de "olhares bovinos" (Maciel 2021), isto é, "uma fala sobre o olhar, ou melhor, o olhar de um animal dotado de um saber sobre a humanidade, que possui um ponto de vista sobre o que vê e uma consciência sobre o objeto de sua visão" (Id.).

\section{Unicamente zoe: a plurisensorialidade ani- mal}

Con esta epígrafe apuntamos á literatura posta en boca dos animais non humanos. Seguindo os estudos de Marta Tafalla, trátase de textos que comprenden o comportamento dos animais ao tempo que valoran as súas calidades sensoriais esteticamente. É dicir, textos que mostran

os animais como suxeitos que posúen capacidades cognitivas, emocionais e comunicativas, capacidades para sentir dor e pracer, memoria e desexos, como suxeitos que desenvolven vínculos afectivos con outros seres e despregan condutas sofisticadas, que entrelazan a súa forma de vida coa contorna á que pertencen e cos outros seres que a habitan. (Tafalla 2019: 195)

Un exemplo desta estética ecoanimal na literatura galega, protagonizada unicamente por animais non humanos, sería o conto "Grieih" (Percival e outras historias) de X. L. Méndez Ferrín. No relato, un grilo e un escornabois senten compaixón, temor, agradecemento, amizade, ledicia, empatía ou amor.

Grieih ollou o monstro ao pasar sobre a súa cabeza e mirouno con curiosidade; as antenas pregadas, pequeneiras e grosas, díronlle idea da ruda bondade e non lle tivo medo ningún (...) Grieih sentiu compaixón do grande coleóptero ferido (...) E foi asín que o escornabois estivo dez ou vinte días case sen se mover. Grieih púñalle de vez en cando unha papa de lama sóbor da chaga, que ía a mellor. (...)

Os ganglios do grilo, a meio devorar, vibraron de ledicia (...) Grieih xacía case desfeito, a pernexar en espasmos, pero tivo forzas pra ollar ao seu vello amigo. (...) E mentres Grieih tivo unha vibración vital, Rasgulkje estivo ao seu carón; desque morreu, ergueu o seu voo, impetuoso e bárbaro, cara o bosco de arriba. (Méndez Ferrín 1994a: 71-73)

Ao noso entender, "Grieih" trátase dunha escritura ecocéntrica que empurra a perspectiva humana cara a un compromiso coa natureza (Gifford 2018: 373). Ademais de ecocéntrica, podería caracterizarse como escrita de teriofilia (Villanueva 2018), é dicir, de admiración polos animais. No texto de Méndez Ferrín non hai unha visión antropomórfica nin se ve o reino

25 Pode profundarse no sentido da vista coa lectura de Birkhead (2019). 
animal a través da nosa limitada existencia (como denunciaba Lucy Cooke), nin se ve a nosa limitada existencia a través do animal ${ }^{26}$. $\mathrm{O}$ autor de "Grieih" é quen de transmitir a mente animal dende o animal, a súa plurisensorialidade, así como o tipo de mundos en que vive.

Por outra parte, no relato percíbese o fundamento da moralidade (empatía e xustiza) entre animais, aspecto que pode localizarse en especies tan diversas como os monos e as ratas (Cooke 2019: 370). Supérase así o risco sinalado por Rebeca Baiceredo "Falar pela boca de outros implica um risco que geralmente acaba por se materializar: anular esse outro que se tenta representar" (Baiceredo 2019: 89).

Non chega a anularse a voz da vaca Cachorra na novela de Afonso Eiré, cuxos exemplos adiantamos no apartado anterior. Non obstante, en Memorias dunha vaca marela vese a nosa limitada existencia humana a través do animal. A voz da vaca aparece como voz narradora para expoñer certa ideoloxía (Orsanic 2018: 63), neste caso a desaparición das formas de vida tradicionais ao carón das consecuencias de determinada política leiteira, máis que como cuestionamento das condicións dos animais (Villanueva 2018: 328):

Así que, o amo e a ama, logo de moito falalo, decidiron mercar unha muxidora. O Xosé foi vela a Castro Candaz o día de feira, xunto aos Hnos. Sánchez. Non era barata, pero moi manexábel. (...) E en quen foi a primeira que probaron...? En min, na pobre da Cachorra, por ser a máis mansa. O Xosé tiña medo a que, ao non estaren afeitas, aquel ruído nos espantase e comezásemos a espernexar e alá fose a máquina ao carallo, co que custaba! (Eiré 2018: 105, 107)

\section{Consideracións finais}

Neste artigo reproducimos textos da literatura galega nos que se aprecia, por un lado, a interconexión humanimal; por outro, a separación entre animais humanos e non humanos en contextos violentos e, finalmente, fragmentos que mostran unicamente a plurisensorialidade animal.

Se xa é habitual non apreciar os animais como suxeitos con capacidades cognitivas, emocionais e comunicativas, capacidades para sentir dor e pracer, memoria e desexos en tempos de paz, aínda se aprecian menos en tempos de violencia. Nin nun tempo nin no outro se pensa que os animais son seres que existan para si mesmos, senón que son reducidos ao valor instrumental que teñan para os humanos (Tafalla 2019: 196) nunha relación suxeito-obxecto. Coincidimos co manifestado por J. Butler (2010: 111) a quen traducimos:

Equivocariámonos se considerásemos o sufrimento algo exclusiva ou paradigmaticamente humano. Os humanos sofren, precisamente, como animais humanos. E, no contexto da guerra, poderíase, e sen dúbida deberíase, sacar a relucir a destrución dos animais, de hábitats e doutras condicións de vida sentiente, citando, por exemplo, os efectos tóxicos das municións da guerra sobre a contorna e ecosistemas naturais e a condición de moitos seres que non poden sobrevivir pero que se atopan saturados de veleno.

Por iso non resulta estraño que a maioría dos textos citados reflictan unha realidade na que os animais existen para nós, para os humanos, para que nos sirvan, para convertelos en ferramentas e roubarlles a súa liberdade. Neste sentido, consideramos interesante o corpus de obras analizadas para reflexionar sobre a nosa relación cos animais e facernos conscientes dos problemas e da dor que lles causamos.

Os autores e autoras dos textos reproducidos mostran as inxustizas, o ecocidio e a condición humana a través de discursos cheos de empatía para fortalecer a conciencia das afinidades sentientes, cognitivas, éticas e emocionais entre as persoas e os animais. Fronte aos medios que nos socializan na opresión e que nos privan da mirada que permite ver o outro (a muller e o animal non humano), a literatura pode acercarnos á relación alterhumana.

Por outra parte, os textos de Méndez Ferrín, presentes nas tres tipoloxías sinaladas neste estudo, reveláronse como fornecedores de múltiples perspectivas para exemplificar a relación humaninal, sobre todo por non converter o animal (mantis, grilo ou escornabois) nun obxecto.

Finalmente, somos conscientes da limitación deste estudo, da provisionalidade de moitas das nosas afirmacións (á espera dunha maior formación), dos fíos soltos e das tarefas pendentes (Pedrosa 2018), de que fuximos dos

26 Parécenos que iso é o que ocorre en obras como Tiempo de perro. Crónica animal de Patrice Nganang. Dentro da nosa literatura, poderiamos exemplificar co relato "O secuestro do poeta" de Héitor Picallo. 
textos en que os animais fosen proxección dos vicios e virtudes humanas para centrarnos en máis dunha vintena de obras que nos permitiron comprobar as relacións humanimais.

En último termo, quereriamos incidir na relevancia dos estudos animais para a construción de vínculos co mundo que nos rodea e cambiar o noso modo de relacionarnos coas outras especies. De logrármolo estariamos no mundo dunha forma diferente (Orsanic 2018). Tal e como mostran os textos literarios citados, existen diversos modos de representar o non humano e a súa relación coa nosa especie, modos que poden axudarnos a cuestionar o dominio humano sobre a natureza e o resto das especies (Verdú e Shiki 2018).

\section{Referencias bibliográficas}

Acuña, Ana (1999): “O concepto e a imaxe da poesía máxico-ritual”, en Rosario Álvarez e Dolores Vilavedra (eds.): Cinguidos por unha arela común. Homenaxe ó profesor Xesús Alonso Montero. Santiago de Compostela: Universidade de Santiago de Compostela, t. 2, pp. 23-40.

Acuña, Ana e Olivia Rodríguez (2018): "Ecocrítica do movemento cultural arredor de Urbano Lugrís", en XII Congreso Internacional da AIEG. Novos horizontes para unha Galicia global. Redes. Territorio. Memoria. Madrid: Universidad Complutense de Madrid, inédito.

Alinei, Mario (1983): "Lo scricciolo ed altri animali magici in Italia: da «parole e cose» a «strutture di cose e di parole»", en C. Angelet, L. Melis, F. J. Mertens e F. Musarra (eds.): Langue, dialecte, littérature. Études romanes à la mémoire de Hugo Plomteux. Leuven: Leuven University Press, pp. 21-33.

Alonso Girgado (1990 [1989]): Antoloxía do conto galego. Século XX. Vigo: Galaxia.

Álvarez Castro, Xosé (2013): Pontevedra nos anos do medo. Vigo: Xerais.

Arendt, Hannah (2006 [1969]): Sobre la violencia. Madrid: Alianza editorial.

Baceiredo, Rebeca (2019): Animais de estimação e bestas de companhia. Santiago de Compostela: Através. Berger, John (1980): Mirar. Barcelona: Gustavo Gili.

Birkhead, Tim (2019): Los sentidos de las aves. Qué se siente al ser un pájaro. Madrid: Capitán Swing Libros.

Braidotti, Rossi (2016): "Catro teses verbo do feminismo posthumano", Grial 54/211, pp. 141-155.

Brito, Nuno (2021): “Um encontro com o outro absoluto: Uma leitura de $O$ animal que logo sou de Jacques Derrida", Dobra 7, 11 pp.

Butler, Judith (2010): Marcos de guerra. Las vidas lloradas. Madrid: Espasa Libros.

Caamaño, Adolfo (2019): Matar o heroe. Vigo: Galaxia.

Cabana, Ana (2019): "Os incendios forestais e a variable xénero: estereotipos de ida e volta", en Proxecto Batefogo (coord.): Árbores que non arden. Vigo: Catroventos, pp. 15-28.

Castro, Francisco (2013): “A corda que aforca o mundo (Historia case real)”, en IES Manuel García Barros: Pedigree. A Estrada: Concello da Estrada, pp. 15-22.

Cooke, Lucy (2019): La inesperada verdad sobre los animales. Barcelona: Anagrama.

Diéguez, Lois (2013): “Como homes”, en IES Manuel García Barros: Pedigree. A Estrada: Concello da Estrada, pp. 23-25.

Docampo, Xabier P. (2005): "Que vén o lobo!”, en Escrita contemporánea. M. Actas das II Xornadas de Literatura Oral. O mito que fascina: do lobo do lobishome. A Coruña: Asociación de Escritoras e Escritores en Lingua Galega, pp. 13-24.

Eiré, Alfonso (2000): Eu tamén fun coas vacas. A Coruña: Espiral Maior.

- (2018): Memorias dunha vaca marela. A Coruña: Hércules Ediciones.

Horta, Óscar (2018): Na defensa dos animais. Rianxo: Axóuxere.

Escartín Gual, Montserrat (2011): "Sentados frente al espejo: el alma de los animales en Unamuno y Coetzee”, en Jimena Rodríguez Carreño (ed.): Animales no humanos entre animales humanos. Madrid: Plaza y Valdés, pp. 155-189.

Flores de la Flor, Ma Alejandra (2011): "Los monstruos híbridos en la Edad Moderna", en Arturo Morgado García e José Joaquín Rodríguez Moreno (eds.): Los animales en la historia y en la cultura. Cádiz: Editorial UCA, pp. 143-152.

Flys Junquera, C.; José Manuel Marrero Henríquez e Julia Barella Vigal (2010): "Ecocríticas: el lugar y la naturaleza como categorías de análisis literario", en Carmen Flys Junquera, José Manuel Marrero Henríquez e Julia Barella Vigal (eds.): Ecocríticas. Literatura y medio ambiente. Madrid: Iberoamericana/ Vervuert, pp. 15-25. 
Flys Junquera, Carmen (2018): "En el principio era la palabra: la palabra y la creación de imaginarios ecológicos”, en José Albelda, José María Parreño e J. M. Marrero Henríquez (coords.): Humanidades ambientales. Pensamiento, arte y relatos para el siglo de la gran prueba. Madrid: Catarata, pp. 182-200.

Fole, Ánxel (1981): “O marco", en Claudio Rodríguez Fer: A Galicia misteriosa de Ánxel Fole. Sada: Ediciós do Castro, pp. 63-66.

(1991): Contos da néboa. Vigo: Galaxia.

Franco Grande, Xosé Luís (2013): “O neno e o pónei”, en IES Manuel García Barros: Pedigree. A Estrada: Concello da Estrada, pp. 35-40.

Garrosa Gude, José Luís (2005): "Unha inquietante presenza: lobos e lobishomes no imaxinario galego e universal", en Escrita contemporánea. M. Actas das II Xornadas de Literatura Oral. O mito que fascina: do lobo do lobishome. A Coruña: Asociación de Escritoras e Escritores en Lingua Galega, pp. 113-143.

Gifford, Terry (2018): "Del medio rural al medioambiente: la escritura británica de la naturaleza en prosa de no ficción", en Margarita Carretero González e José Marchena Domínguez (eds.): Representaciones culturales de la naturaleza alterhumana. Aproximaciones desde la ecocrítica y los estudios filosóficos y sociales. Cádiz: Editorial UCA, pp. 363-379.

Glotfelty, Cheryll (2010): "Los estudios literarios en la era de la crisis medioambiental", en Carmen Flys Junquera, José Manuel Marrero Henríquez e Julia Barella Vigal (eds.): Ecocríticas. Literatura y medio ambiente. Madrid: Iberoamericana/Vervuert, pp. 49-65.

Gomes Bastos, Lucas (2021): "De humanos animais e animais humanos: Gregor Samsa e Pedro Vermelho", Dobra 7, 11 pp.

González Torres, Yolotl (2018): "La fauna en el pensamiento mesoamericano", en Margarita Carretero González e José Marchena Domínguez (eds.): Representaciones culturales de la naturaleza alterhumana. Aproximaciones desde la ecocrítica y los estudios filosóficos y sociales. Cádiz: Editorial UCA, pp. 131-161.

Guida, Ângela (2021): “O vis-à-vis com o animal que logo somos: entre linhas, versos e tintas", Dobra 7 , $12 \mathrm{pp}$.

Iglesias, Xosé (2014): Tranfusión oceánica. Malpica: Caldeirón.

- (2016): A relixión do mar. Gondomar: Instituto de Estudos Miñoráns.

Kailo, Kaarina (2015): “Del patriarcado como sistema alquímico a la alternativa: el imaginario del don”, en Alicia H. Puleo (ed.): Ecología y género en diálogo interdisciplinar. Madrid: Plaza y Valdés editores, pp. 359-373.

Levi, Primo (2015 [1987]): Trilogía de Auschwitz. Barcelona: Península.

Lueiro Rey, Manuel (2003 [1982]): O sol na crista do galo (Edición de Ramón Nicolás). Vigo: Xerais.

Maciel, Maria Esther (2021): "Literatura e subjectividade animal”, Dobra 7, 11 pp.

Marco, Aurora (2011): Mulleres na guerrilla antifranquista galega. Ames: Laiovento.

Martín, Paco (2000 [1992]): Historias para ler á noite. Vigo: Galaxia.

Méndez Ferrín (1987 [1971]): Retorno a Tagen Ata. Vigo: Xerais.

—_ (1994a [1958]): Percival e outras historias. Vigo: Xerais.

(1994b): Estirpe. Vigo: Xerais.

(1999 [1991]): Arraianos. Vigo: Xerais.

(2004 [1980]): Crónica de nós. Vigo: Xerais.

Morgado García, Arturo (2015): La imagen del mundo animal en la España Moderna. Cádiz: Editorial UCA.

Morpurgo, Michael (2012): Caballo de batalla. Barcelona: Noguer.

Murado, Miguel Anxo (2000 [1995]): Ruído. Relatos de guerra. Vigo: Galaxia.

Neira Vilas, Xosé (1979 [1961]): Memorias dun neno labrego. Sada: Ediciós do Castro.

Nganang, Patrice (2010): Tiempo de perro. Crónica animal. Barcelona: El Aleph.

Orsanic, Lucía (2018): “Imágenes caninas medievales. Textos y contextos”, en Margarita Carretero González e José Marchena Domínguez (eds.): Representaciones culturales de la naturaleza alterhumana. Aproximaciones desde la ecocrítica y los estudios filosóficos y sociales. Cádiz: Editorial UCA, pp. 59-80.

Osorio, Rodrigo (ed.) (2021): Orixe orzánica das sereas todas. Santiago de Compostela: Alvarellos. 
Palacios, Manuela (2017): “Travesías das baleas pola poesía contemporánea de Galicia e Irlanda: Xénero, empoderamento e extinción", Madrygal. Revista de Estudios Gallegos 20, pp. 127-145, https://doi. org/10.5209/MADR.57634.

Parreño, José María e J. M. Marrero Henríquez (2018): “Presentación. La cultura del Antropoceno”, en José Albelda, José María Parreño e J. M. Marrero Henríquez (coords.): Humanidades ambientales. Pensamiento, arte y relatos para el siglo de la gran prueba. Madrid: Catarata, pp. 7-14.

Pedrosa Bartolomé, José Manuel (2010): "Ecomitologías", en Carmen Flys Junquera, José Manuel Marrero Henríquez e Julia Barella Vigal (eds.): Ecocríticas. Literatura y medio ambiente. Madrid: Iberoamericana/Vervuert, pp. 313-337.

Picallo, Héitor (2013): "O secuestro do poeta”, en IES Manuel García Barros, Pedigree. A Estrada: Concello da Estrada, pp. 75-82.

Pimentel, Luís (1983): Sombra do aire na herba. Vigo: Galaxia.

Pons Prades, Eduardo (2004): Los niños republicanos en la guerra de España. Madrid: Anaya.

Puleo, Alicia H. (2013 [2011]): Ecofeminismo para otro mundo posible. Universitat de Valencia: Cátedra. (2019): Claves ecofeministas. Para rebeldes que aman la Tierra y a los animales. Madrid: Plaza y Valdés.

Queipo, Xavier (2013): "Resistencia acuática”, en IES Manuel García Barros: Pedigree. A Estrada: Concello da Estrada, pp. 89-91.

Risco, Vicente (1990 [1925]): “O lobo da xente”, en Luis Alonso Girgado: Antoloxía do conto galego. Século XX. Vigo: Galaxia.

Rivas, Manuel (2008 [1993]): En salvaxe compaña. Vigo: Xerais. (2020): Zona a defender. A esperanza indócil. Vigo: Xerais.

Rodríguez Fer, Claudio (1981): A Galicia misteriosa de Ánxel Fole. Sada: Ediciós do Castro.

Salgado, Xosé M. e Xoán-M. Casado (1989): X. L. Méndez Ferrín. Barcelona: Sotelo Blanco.

Sánchez Arins, Susana (2015): Seique. Santiago de Compostela: Através.

Sarille, Xosé Manuel (2004): Polos fillos dos fillos. Santiago de Compostela: Candeia.

Sierra Veloso, Xurxo (2020): Benvidos á cidade. Vigo: Galaxia.

Singer, Peter (2018): Liberación animal. Segunda edición ampliada. Barcelona: Taurus.

Souto, Paco (2016): e Caín. Santiago de Compostela: Laiovento.

Souto, Xurxo (2004): Contos do mar de Irlanda. Vigo: Xerais. (2007 [2001]): Contos da Coruña. Vigo: Xerais.

(2018): A gran travesía de Chiruca Macallás. Vigo: Xerais.

(2021 [1999]): O retorno dos homes mariños. Vigo: Xerais.

Tafalla, Marta (2019): Ecoanimal. Una estética plurisensorial, ecologista y animalista. Madrid: Plaza y Valdés.

Velasco Sesma, Angélica (2015): "Más allá del mecanicismo: heroínas ecológicas del imaginario actual”, en Alicia H. Puleo (ed.): Ecología y género en diálogo interdisciplinar. Madrid: Plaza y Valdés editores, pp. 341-358.

(2018 [2017]): La ética animal. ¿Una cuestión feminista?. Universitat de Valencia: Ediciones Cátedra.

Verdú Delgado, Ana Dolores e Teresa Shiki (2018): “Alteridades sin barreras. Relación entre lo humano y lo alter-humano en la cosmovisión animista shuar", en Margarita Carretero González e José Marchena Domínguez (eds.): Representaciones culturales de la naturaleza alterhumana. Aproximaciones desde la ecocrítica y los estudios filosóficos y sociales. Cádiz: Editorial UCA, pp. 163-182.

Villanueva Romero, Diana (2018): "Una visión alter-humana del futuro del planeta: Ishmael y Juicio a los humanos", en Margarita Carretero González e José Marchena Domínguez (eds.): Representaciones culturales de la naturaleza alterhumana. Aproximaciones desde la ecocrítica y los estudios filosóficos y sociales. Cádiz: Editorial UCA, pp. 325-342.

Xubín, Isaac (2012): Con gume de folla húmida. Santiago de Compostela: Sotelo Blanco. (2016): Non hai outro camiño. Vigo: Xerais.

(2019): Os largos e longos campos de liño azul. Vigo: Galaxia. 